This PDF is a selection from an out-of-print volume from the National Bureau of Economic Research

Volume Title: National Income and Its Composition, 1919-1938, Volume I

Volume Author/Editor: Simon Kuznets, assisted by Lillian Epstein and Elizabeth Jenks

Volume Publisher: NBER

Volume ISBN: 0-87014-039-6

Volume URL: http://www.nber.org/books/kuzn41-1

Publication Date: 1941

Chapter Title: Distribution of National Income

Chapter Author: Simon Kuznets, Lillian Epstein, Elizabeth Jenks

Chapter URL: http://www.nber.org/chapters/c4226

Chapter pages in book: (p. 61 - 95) 


\section{Distribution of National Income}

A NATIONAL income total for a given country and period can be apportioned among smaller spatial units or shorter periods. For example, national income for the United States can be apportioned according to its origin in the various states or in still smaller territorial units. An annual total can be apportioned among quarters or months to give a more sensitive record of temporal changes. But we are not concerned with such distributions, largely because our estimates are for the country as a whole and annual. Our interest lies instead in distributions that reflect substantive rather than formal characteristics. To what uses is the monetary equivalent of national income put; by what industries is the net national product turned out; what are the attributes of the various factors in the production process and the qualities of goods comprising national income?

Three main types of distribution based on these characteristics are attempted in our estimates: (1) among withholdings, disbursements, and consumers' outlay; (2) by industrial origin; (3) by type of income or payment, representing compensation for various kinds of productive service. They are discussed here in order to clarify the meaning of the constituents of each classification; to indicate the difficulties encountered in defining these classifications precisely; and to explain how exigencies force us to depart at some points from the allocations that would best serve the purpose underlying the classification. 


\section{$I$ Among Withholdings, Disbursements, and Consumers' Outlay}

In the preceding chapter (Sec. $5 \mathrm{~A}$ ) we mentioned that between the completion of the production process, whose net yield constitutes national income, and the end of the process of ultimate consumption, there are two intermediate phases at which we can measure aggregate payments to individuals and consumers' outlay. Treating these two and ultimate consumption as parts of national income, we arrange in the accompanying tabulation the complementary categories which, together with payments, outlay, or consumption, add up to national income. The order on the left side is dichotomous for each of the four larger magnitudes; on the right side it is sequential, showing the number of categories (over two) into which national income can be divided.

I National Income

1 Aggregate payments to individuals

2 Net savings of corporations and governments

National Income

1 Net savings of corporations and governments

2 Net savings of individuals and entreprencurs

II Aggregate Payments to Individuals 3 Consumers' outlay and Savings of Entrepreneurs

1 Consumers' outlay

2 Net savings of individuals and entrepreneurs

National Income

1 Net savings of all enterprises

2 Net savings of individuals

3 Consumers' outlay

\section{National Income}

2 Net savings of inclividuals

IV Consumers' Outlay

I Net savings of all enterprises

2 Net savings of individuals

1 Ultimate consumption

2 Net changes in consumers' inventories

3 Net changes in consumers' inventories

4 Ultimate consumption 


\section{A INCOME PAYMENTS AND SAVINGS OF ENTERPRISES}

Enterprises do not necessarily disburse to individuals amounts equal to the net product originating during the year. A business corporation may not pay to individuals in wages, salaries, dividends, interest, etc. a sum exactly equal to the difference between the gross value of its product and the value of goods consumed in turning out this product. In prosperous years corporations often disburse less than this difference, retaining some positive net savings; in poor years they often disburse more, sustaining negative net savings. Any enterprise whose activity is included in national income may have different amounts of net income originating and total payments to individuals.

The distinction seems simple, but its application is not. How should we treat payments to individuals that cannot be interpreted as compensation for their services or the services of their property utilized in current production? Obviously, such payments may be of two types: (1) Enterprises may make payments which, while not in compensation for services to current production, may yet be in payment for past services (or sometimes even future). A clear case is that of pensions paid by business firms to their retired employees. (2) Enterprises may make payments whose connection with past, present, or future production is tenuous; e.g., contributions by business firms to community chests or other charities, or relief and public assistance payments by governments.

In either type we can include the disbursements under aggregate payments to individuals and estimate the net savings of the disbursing enterprises after the deduction of these disbursements; or exclude them from aggregate payments to individuals and estimate net savings prior to their deduction. Whichever we do, they are included or excluded under national income as they are or are not paid out of the current net value product.

Our practice has been to include such disbursements as pensions, contributions, and relief under aggregate payments 
to individuals and estimate net savings of enterprises after their deduction. For pensions and similar payments connected with past or future services, we can readily justify our practice. It is never too easy to say that any payment is necessarily in compensation for services in current production (consider dividends paid by a corporation in a year of greatly reduced activity, i.e., payment of a discretionary character for the use of a property that fails to earn a corresponding return); and it is more practicable to allow for discrepancies in timing between payments and current production. But an even better reason for including such disbursements under aggregate payments to individuals is that, unlike other net savings (which ordinarily assume the form of cash, inventory, equipment, or reduction in net indebtedness), they do flow to individuals and are not retained by enterprises; and that we are interested in all payments by enterprises to individuals, so long as the nexus between the two is one of some sharing by individuals in the production processes of the enterprises.

The case for the inclusion of contributions and relief and public assistance payments under aggregate payments to individuals is less clear, although even here some connection may be found with past or future services of individuals in the production process. Yet the alternative, i.e., to include them under net savings of enterprises, would yield more misleading results. Of course, these disbursements could be omitted from both payments to individuals and net savings of enterprises and treated as an inevitable cost of carrying on the production process. But this treatment would be even more misleading since it would understate national income and fail to measure properly disbursements by enterprises to individuals. For these reasons, we included relief and similar payments under aggregate payments to individuals and estimated net savings of enterprises after the corresponding deductions.

Our aggregate payments, consequently, include all disbursements by enterprises to individuals qua individuals, and since some represent compensation for current services and others 
have merely an indirect relation to them we must classify all in more detail (Sec. 3).

The distinction between income payments and net savings seems clear for business corporations, difficult as it may be to establish statistically. But for governmental agencies and unincorporated firms it is more complicated. The distinction between payments to individuals and net savings of enterprises implies that the gross value of product, minus the cost of goods consumed, can be compared with aggregate payments to individuals qua individuals. However, in the case of governmental agencies it may be argued that total receipts do not measure the gross value of product and that the latter should be measured by some other yardstick. If the cost of governmental activity is the yardstick, then net income originating and aggregate payments by governments to individuals must be equal.

In the preceding chapter (Sec. $3 \mathrm{C}$ ) we gave our reasons for using the payment-price basis for valuing governmental services. If this decision is accepted, the distinction between payments to individuals and net savings by governments parallels that for business enterprises. We mention it here in order to emphasize that the application of the dichotomy under discussion is dependent upon how governmental services are valued.

In an unincorporated firm the entrepreneur is both the recipient of disbursements from it and the man who decides how much of its net income should be withdrawn and how much should remain as its net savings. Can we differentiate between net income originating and income payments to the entrepreneur? It may be argued that the latter comprise the entire residue of net income originating, after payments to other productive factors have been made; that the entrepreneur whose firm has positive or negative savings is like any other ultimate recipient of income payments who may decide to reinvest part of his income in the enterprise that employs him or to withdraw part of his accumulated savings. If the argument is valid, there is still a significant difference between 
entrepreneurial withdrawals for consumption (or investment elsewhere) and the total net income accruing to the entrepreneur in his firm. But the difference is similar to that between total payments to ultimate recipients and consumers' outlay, and should not be treated as if it were similar to the difference between net savings of enterprises and payments to individuals.

Or, it may be argued that savings of unincorporated enterprises are different from savings of individuals as individuals. For the latter, saving is the result of decisions made with reference to a freely disposable income. An individual receives a salary, wage, dividend or withdraws a certain amount from his firm. The payments are usually in the form of freely disposable means; and although the income of every individual is subject to many unavoidable drafts, there is a freedom of disposition that is one of the consequences of a fully developed monetary system and a distinguishing feature of an actual payment received. On the other hand, considered as an addition to the individual entrepreneur's disposable income, the savings, whether positive or negative, of the firm itself are partly an accounting fiction. The savings that appear at the end of the year may be due to an improvement in accounts receivable or inventory position; and it would be difficult to claim that the entrepreneur, after calculating the net income that accrues to him during the year, decided to reinvest part of it in additional accounts receivable or inventories, a decision similar to one made by an individual investing freely disposable funds in stocks or bonds. Net savings of unincorporated firms can, therefore, be viewed as arising from the same mixture of discretion and helplessness as net savings in most business enterprises. Consequently, entrepreneurial net income should be differentiated from entrepreneurial withdrawals, and net savings of unincorporated firms included in net savings of enterprises and excluded from aggregate payments to individuals.

Since it seems to us that the balance of analytical considerations is in favor of treating net savings of unincorporated firms 
as savings of enterprises rather than of individuals, we have tried to separate entrepreneurial net savings from withdrawals; although in the present state of the data the measurement of the differences is exceedingly rough and tentative. We give estimates of savings of all enterprises and payments to individuals, excluding entrepreneurial net savings. But since the alternative viewpoint is tenable, we give also estimates corresponding to it and allow for it in the classification above. In this alternative treatment payments to individuals include net savings of unincorporated firms; net savings of enterprises exclude them; and income payments to entrepreneurs are considered to be equal to the total net income of entrepreneurs, including savings of their firms.

\section{B CONSUMERS' OUTLAY AND INDIVIDUALS' NET SAVINGS}

Aggregate payments to individuals represent the means of payment the economic system places at the disposal of ultimate consumers, constituting their main, but not sole, source of purchasing power: consumers may draw upon their accumulated assets or use credit to supplement their current income.

Consumers' outlay designates the sum spent by ultimate consumers during the year on finished commodities and services. It can be either smaller or larger than aggregate payments to individuals. Ultimate consumers, singly or in toto, can spend less than they receive from producing enterprises, realizing positive net savings and improving their net monetary or claims position; or they can spend more, sustaining negative savings and worsening their net monetary or claims position. Since consumers' outlay measures expenditures on finished consumer goods, and individuals' savings are the main source from which capital formation is financed, we divide aggregate payments to individuals into these two parts.

Two observations should be made about this dichotomy. First, the distinction between consumers' outlay and individuals' savings rests, in the final count, upon the definition of ultimate consumption and finished goods. If we consider edu- 
cation as ultimate consumption, then expenses for it become part of consumers' outlay. But if education is treated purely as preparation for economic activity and consequently a species of investment, expenses for it should properly be treated as part of individuals' net savings. The conclusion we reached in the preceding chapter (Sec. 4), that only such consumption is intermediate as represents utilization by business and public enterprises of commodities and of services of other enterprises, is relevant here. In accordance with it, consumers' outlay comprises all expenditures by individuals and households on products of enterprises except those incurred by the former as members of business and public enterprises; individuals' savings are, then, the difference between aggregate payments and consumers' outlay. ${ }^{1}$

The second observation relates to the measurement of both consumers" outlay and individuals' savings when the immediate payment does not cover the full price of the product. If a household buys an automobile or refrigerator on an installment basis, should consumers' outlay for the year include the full value of the purchase or only the amount actually paid during the year? How should purchases on which there was no payment at all during the year, but only a corresponding increase in consumers' debts, be treated?

The questions are similar to those discussed in establishing the timing of production (see Ch. 1, Sec. 5 B). But the argument that production is a continuous process and cannot be treated as occurring only at the instant the product appears on the market cannot be applied to purchasing. It would be unrealistic to assert that purchasing is a continuous process, and that a man who buys a car on an installment basis is engaged in continuous purchasing during the entire period he is making payments. Nor is it realistic to assert that a purchase or outlay takes place at the time the payment is made rather

1 Since we include net imputed rent from owner-occupied houses in national income, the owner-occupied unit is treated as an enterprise. Purchases of houses represent, therefore, use of savings, not consumers' outlay. 
than at the time the good changes hands and the purchaser assumes the obligation to pay. The distinction between consumers' outlay and individuals' savings is consequently a more useful tool in economic analysis if the outlay includes the value of all goods that pass from the effective possession of enterprises to that of ultimate consumers, and if accordingly total individuals' savings are scaled down by the value of obligations that ultimate consumers may have assumed in purchasing goods on credit. This interpretation, modified by exigencies of data, is followed in deriving our estimates. ${ }^{2}$

\section{ULTIMATE GONSUMPTION AND GHANGES IN CONSUMERS' IN- VENTORIES}

The services of finished goods purchased by ultimate consumers are not absorbed immediately, i.e., they are not immediately and exhaustively applied to the satisfaction of consumers' wants. The interval between the dates of purchase and of the exhaustion of services is relatively brief for perishable goods but substantial for others. If a smaller amount of goods is consumed during the year than is purchased, the stock held by ultimate consumers, viz., consumers' inventories, increases. Or, to the extent that consumers' inventories exist at the beginning of the year, ultimate consumption may exceed consumers' outlay, causing a decline in consumers' inventories.

Obviously, changes in consumers' inventories must be analyzed if the structure of ultimate demand and fluctuations in it are to be understood. Unfortunately, relevant data are few and not easy to obtain. Ultimate consumption and changes in consumers' inventories occur entirely within the household economy; economic study, on the contrary, tends to concentrate on processes observable in the market place.

In dividing consumers' outlay into ultimate consumption and changes in inventories, the major task, if we disregard the almost complete absence of relevant statistical data, is to esti-

2 Such treatment implies that a return to a business enterprise of goods bought by an ultimate consumer should enter consumers' outlay with a negative sign. 
mate the current consumption of durable goods. As in the case of productive enterprises using durable capital equipment, it is difficult to estimate consumption for time units shorter than the entire life of the good. Moreover, ultimate consumers, unlike business enterprises, are not forced by necessities of accounting and taxation procedure to estimate such consumption; and the calculation of current depreciation and obsolescence is often neglected even for such goods as a house or a passenger car, let alone other finished goods that represent a smaller outlay.

Another factor that makes it difficult if not impossible to estimate the current consumption of consumers' durable goods is the luxury quality many of them have, in consequence of which their utilization has a strong flavor of ostentation. In times of stress an ultimate consumer may use his car or house much longer than otherwise and forego the kudos enjoyed by possession of a new one. Since durable equipment used by business enterprises seldom possesses such luxury elements, its consumption is more strictly controlled by the calculation of costs and returns and, as a result, is a more nearly determinable quantity than the consumption of consumers' durable goods.

Nevertheless, consumption and changes in consumers' inventories can now be measured for some commodities, and will become measurable for more as data accumulate. At present the data are too meager for us to estimate consumers' outlay other than as a whole. But there are strong indications that the increasing prominence of durable goods in the expenditure pattern of ultimate consumers will stimulate the measurement of changes in consumers' inventories.

\section{By Industrial Origin}

Industries differ in the raw materials utilized, production processes carried on, and products turned out. Raw materials differ in the degree to which their sources are concentrated territorially; in reproducibility and susceptibility to technical control; in exhaustibility and tendencies toward increasing 
costs or diminishing returns; in perishability, quality, and many other technological properties. Production processes differ in the size of the unit that can most advantageously be operated; in the ratio of direct labor and durable capital equipment to raw materials consumed; in the extent to which physical transformation of raw materials takes place; in the temporal continuity of operations; in the relation of vital phases of the process to skill, etc. Completed products of industries differ in their distance from the stage at which they are ready for ultimate consumption; in perishability over time and in durability in the process of use; in the primacy and urgency of the ultimate needs they satisfy; and so on through the various physical characteristics of products distinguishable according to their final use.

Superimposed upon these purely technological characteristics of materials, processes, and products are the peculiarities of social and economic organization, which also differ fundamentally from industry to industry. Some industries have mainly country sites; others are perforce concentrated in big cities. In some industries numerous small unincorporated enterprises predominate; in others, entrepreneurs do not exist and control is concentrated in huge semi-public or public corporations. In some industries competition among enterprises is fairly effective, in others there is no competition. In some industries overhead costs are minor compared with direct costs; in others, the opposite is true. Some industries cater to recipients of large incomes; others depend upon the mass demand of moderate and low income groups.

This combination of differences in technological characteristics and social and economic organization is an important datum in the understanding and measurement of economic phenomena. If measurement is to be helpful in revealing the factors that make for change and the way economic changes take place, study of how industries differ is indispensable: the technological characteristics of materials, processes, and products and the peculiarities of economic organization spell 
differences in response during both short and long periods. If an appraisal is involved, as in national income measurement, industrial differences must be kept in mind, for they reveal the areas in which the common yardstick used may have somewhat different meanings, and suggest the group composition of the body social for whose satisfaction national income is used.

\section{A NATIONAL INCOME}

The distribution of national income among industries is of the net value originating, not of the total value of an industry's product. For some purposes, such as estimating waste involved in an 'unproductive' industry, this is a disadvantage since we need the gross value. Net income originating in various industries may be interpreted as the contribution of each to the common pool of goods we call national income; or may be considered a measure of the cost to society of the activities carried on by each. Both interpretations are applicable to income originating in any single industry, and care must be taken not to switch, without good reason, from the one interpretation for one industry to the other for another industry.

Interest in ascertaining how much various industries contribute to a given national net product or how much they claim in compensation for their activity stems largely from the differences in their activities. An increase or decrease in national income arising from a corresponding change in the net value originating in agriculture is not open to the same interpretation as an equal change in national income attributable to an increase or decrease in the net value originating in finance.

If an industrial distribution is to provide bases for proper understanding, each category in it must be well defined. Similar productive activities should not be included under different industrial divisions; no divisions should include essentially different activities; the classification should be complete, i.e., not exclude activities of some importance in the economic system; and should contain no false categories that would give 
to purely transfer and auxiliary functions the semblance of a separate industry. To establish an industrial classification free from such defects is exceedingly difficult because (1) diverse productive activities are carried on in one operating or business unit; (2) productive activities and purely ownership functions are carried on in one business unit; (3) the productive activities carried on by operating and management units ostensibly belonging to one and the same industry change.

1) One operating unit often carries on diverse productive activities, e.g., both extractive and manufacturing activities or both manufacturing activities and trading functions; or combines the production of commodities, transportation, and power with construction. The activities are significantly disparate. Mining is different from manufacturing in that location and exhaustibility of natural resources are more vital to the former than to the latter. The functions performed by steam railroads and other public utility industries are continuous; construction is seasonal. Manufacturing is concerned with changing the form of commodities; merchandising, with their distribution. Yet within operating units, i.e., within the establishments directly engaged in production, a mixture of these productive activities is common. To allocate the net income originating in the enterprise among the different productive functions is a task obviously beyond the powers of a national income investigator, since it would require exceedingly detailed cost accounting and some arbitrary allocation of joint costs.

Business or management units carry on diverse productive functions even more commonly than operating units. An enterprise, whether incorporated or unincorporated, may comprise several plants, offices, agencies, which are often engaged in production of different types, though usually complementary to one another. Certain components of net income originating in the enterprise-property income, overhead salaries and, of course, net savings-are ordinarily not allocated to the various operating units, but are given for the enterprise as a 
whole. Consequently, in distributing them, and hence national income, by industries, we encounter a mixture of productive functions within larger business units even more frequently than within operating units.

2) Enterprises can act not only as producing entities but also as ownership units. A corporation may receive dividends and interest from other business enterprises, and in turn pay dividends and interest to them. Do the payments received represent compensation for goods produced by it or payments to it as an investor, i.e., as a possessor of property and funds it does not itself utilize? If the payment is to the enterprise as a producer, the net income to which it gives rise may be considered to originate in the receiving enterprise. But if the payment is to the enterprise purely as an owner, the net income to which it gives rise obyiously originates in the paying enterprise.

This distinction demands that we answer two questions when we attempt an industrial distribution of a national income total. First, how shall we treat enterprises obviously engaged in productive activity but still deriving part of their gross revenue from ownership, i.e., receiving income on investments? In this case income in the form of dividends and interest originates in the paying enterprise, not in the receiving. Accordingly, in establishing net income originating in a given economic unit we must subtract from its gross receipts not only the cost of goods consumed but also the part of the gross receipts that represents compensation for pure ownership. So far as data are available on inter-enterprise receipts of dividends and interest, we can and do follow this procedure.

Second, how shall we treat enterprises that are largely ownership units and in which the share of productive activity in total income may be relatively small? Savings banks and insurance companies, which are engaged primarily in placing the accumulated savings of individuals at the disposal of industry, are good illustrations. In the process of mobilizing individuals' savings and selecting the place for investment, 
they produce net income, i.e., the net value of the services of individuals and capital engaged in them. In addition, they earn net income, part of which may be retained temporarily but the bulk of which goes to policyholders and depositors. Can interest paid to depositors by savings banks and the net savings of the latter be considered as arising in the banking industry? Or the payments to policyholders by insurance companies and the net savings of the latter as arising in the insurance industry? A similar question can be raised about payments to investors by all institutions engaged in placing idle balances at the disposal of productive enterprises.

Unless the industrial distribution of national income is to lose most of its meaning, it cannot be so applied as to attribute net savings and payments to depositors by banks, insurance companies, etc. to the banking and insurance industries. If this is done, what is to bar an interpretation of investment as an industry, and of dividends and interest received by wealthy families (who may have formed a personal corporation) as income originating in the 'investment' industry? We must recognize the possibility that payments may be transferred from one group of enterprises to another, and that a given group of enterprises may be, with respect to some of the income streams passing through them, not much more than an association of individuals in their capacity as investors and ultimate income recipients.

Hence, income originating in such industries as savings banks and insurance is confined to the net value of the services of individuals engaged in them, and excludes payments to depositors and policyholders as well as the net savings of the enterprises. These payments and savings are treated as originating in the industries from whose stocks and bonds the enterprises receive their revenue. ${ }^{3}$

3) The effect of carrying on diverse productive functions

3 This does not dispose of some technical difficulties introduced by the absence of relevant data or of questions arising in connection with the treatment of rent. The latter are discussed in Section $3 \mathrm{~A}$; the former, in Part Four. 
within operating or business units and of combining productive activities with purely ownership functions within one enterprise would be reduced appreciably if they always remained the same. But they are susceptible to change. Changes in technology make for shifts in the relative importance of various types of productive function within one operating unit. Shorter term cyclical fluctuations lead to fluctuations in the distribution of the working personnel and of the active time a single plant devotes to turning out the finished product and auxiliary operations such as repairs and construction; or to production and merchandising. The housing of several operating units within one enterprise is the result and the essence of the process of industrial integration that developed rapidly during the last decades of the nineteenth century and is still proceeding at a fast pace. Inter-enterprise payments of dividends and interest arising from interlocking ownership are another facet of the same process. And the extent to which individuals place their savings with insurance companies, savings banks, and similar institutions is also changing. Since complete adjustment is impossible, the industrial distribution is not precise and the blurred area changes from one period to another.

Moreover, comparisons over time must also take account of the changes that may have occurred in the productive activities classified as belonging to one and the same industry. The functions of retail trade, professional service, government, and many other branches of the productive system are quite different today from what they were fifty years ago. The name remains the same, but activities subsumed under it change, without necessarily reducing or increasing the mixture of types of productive activity.

Any distribution of national income by industrial origin is thus subject to serious qualifications. In the nature of the case, it cannot be accurate for clearly demarcated functional types of productive activity. At best it is a distribution among the institutional categories designated as industries, and its 
interpretation must be qualified accordingly. For example, if the estimates show that manufacturing accounts for $x$ and trade for $y$ per cent of national income, this does not mean that $x$ measures accurately the share of activity concerned with transforming commodities, or $y$ the share concerned with the exchange and distribution of commodities among enterprises and between enterprises and households. Some trading functions may be performed by 'manufacturing' and some manufacturing activity by 'trade'. Similarly, an increase in the share of trade and a decrease in the share of manufacturing does not necessarily mean that distributive activity contributes or claims an increasing share of the national product, and manufacturing activity a declining share. It may well be that certain distributive functions formerly carried on by manufacturing enterprises and included under manufacturing have been shifted to wholesalers and retailers, thereby swelling net income originating in trade. Similarly, an increase in the share of income originating in governmental activity does not necessarily mean that either the price or quantity of governmental services proper has increased relatively to the price or quantity of goods provided by the private business system. It may mean merely that governmental agencies have taken over some activities formerly pursued by private business, or have been forced into new activities.

Since the shifts and overlapping are minor in comparison with the persistent and significant differences among categories, these limitations do not render an industrial distribution of national income worthless. The institutions called agriculture, mining, manufacturing, steam railroading, etc., while containing enterprises that combine productive activities of diverse types, are largely dominated by distinctive productive functions. The element of pure trading is minor in manufacturing, as is the element of pure manufacturing in trade. When really significant changes do occur, the institutional categories also shift, i.e., new industries are recognized and old industries dropped. The lack of strict correspondence between the insti- 
tutional categories and the strictly functional segregation of types of productive activity is important merely as a qualification that should prevent erroneous interpretations of differences or changes in the estimates.

B SAVINGS OF ENTERPRISES AND AGGREGATE PAYMENTS TO INDIVIDUALS

Net savings of enterprises suggest the amount of funds made available for investment without recourse to banks and the outside money market, or the amount of disinvestment susstained. The amounts have a high prognostic value, since usually enterprises that enjoy large positive net savings demonstrate thereby their favorable market position and are likely to expand their activities in the future; while enterprises sustaining large negative savings will naturally be forced to curtail their activities. What is true of enterprises is, somewhat less directly, true of industries. Therefore, the industrial distribution of net savings of enterprises reveals one of the prime factors making for changes in the relative importance of various industries in the country's total. It is subject to the same qualifications as a distribution of national income by industrial origin.

Somewhat similar reasoning can be applied to suggest why we allocate aggregate payments to individuals by industries. So far as changes in total payments differ from industry to industry, the analysis of aggregate payments must rest upon its distribution among industrial branches. The use of an industrial distribution of aggregate payments is thus coordinate with that of national income, and is also subject to all the limitations discussed above.

A distribution of aggregate payments to individuals by industrial origin may serve also to demarcate groups in the body social. Most of the people who derive their income from agriculture reside in the country and pursue a mode of life quite different from that followed by people attached to other industries and dependent upon income payments originating in 
them. Similarly, miners, employees of manufacturing enterprises, people engaged in trade or in professional pursuits, etc. form fairly distinct social groups. Since the pattern of expenditures and savings may well differ for each group, an industrial distribution of payments would assist not only in understanding the background of conflict and cooperation within at least one set of social groups but also in analyzing changes and differences in the division of payments between consumers' outlay and net savings and the apportionment of consumers' outlay among finished goods of various types.

A distribution of income payments by industrial origin is, however, merely a rough approximation to what is wanted and fails to conform to two essential conditions. If our interest lies in the income of various social groups differentiated largely by their industrial attachment, we should estimate total income payments received by each, and exclude income payments that cannot be interpreted as receipts by members of a group with a given industrial attachment. For example, by estimating income payments originating in agriculture we account for the major part of farmers' current income and segregate the part of aggregate income payments that is received primarily by a social group called farmers. But total income payments originating in agriculture are both too small and too large for our purpose: too small because they cover only payments farmers receive from agriculture and exclude payments farmers receive as compensation either for direct services to other industries or for property invested otherwise than in agriculture; too large because they include payments not only to farmers but also to individuals who have little connection with agriculture and do not depend upon it for their income, e.g., holders of farm mortgages. For any industry the amount of payments originating tends to differ in these two respects from the total income of the group attached to it.

The industrial allocation of property income, dividends, interest, and to some extent rent is especially difficult to interpret in terms of social groups, for the recipients do not actively 
participate in the industries that are the sources of this income. When merely a minor portion of the income of individuals or households is derived from property, where it originated does not help in classifying recipients by social groups. When property is the major source, receipts are likely to come from diverse industrial sources, and dependence upon a single industry is probably uncommon.

The industrial distribution of aggregate payments to individuals is more significant when applied solely to payments that represent compensation for direct services. The industrial distributions of wages, salaries, and entrepreneurial income reflect the apportionment of the proceeds of industry to groups differentiated by their industrial attachment. But even this narrowing of the scope of payments to be allocated still leaves the distribution merely an approximation. It is not unusual for an individual to derive income from more than one industry (either from seasonal or part-time jobs or from divers industrial attachments, common among the professions). Such inter-industry combinations are even more common within households or economic families, in which one income earner may be engaged in one industry and another in a different one. And the household as consumer rather than the individual as producer is the unit by which income receipts of social groups are classified.

Despite these limitations, the second meaning of the industrial distribution of aggregate payments to individuals is significant. Payments originating in an industry are a tolerable approximation to the total receipts of people attached to it; and can be derived in large part from the body of data upon which the industrial distribution of national income rests.

\section{Of Income Payments by Type}

The classification of income payments by type is based largely upon differences in the functions performed by the recipients. Differentiation among these functions is based in turn upon whether the recipient himself engages in the production proc- 
ess or participates solely through his property; upon the directness of his participation, if active; upon the extent to which he shares in the management and disposition of the enterprise's activities; upon the character of his property claims. Applying these criteria yields the usual classification of income payments by type-wages, salaries, other income of employees, entrepreneurial withdrawals or net income, dividends, interest, rent, royalties, etc.

A PAYMENTS FOR SERVICES OF INDIVIDUALS AND OF PROPERTY The most fundamental distinction is perhaps between payments for the services of individuals and of property. The former are based on direct participation in the production process-the commonest form of economic activity, absorbing the major part of active economic agents' attention, imposing a pattern on the life they and their families lead, and demanding at times considerable sacrifice. Participation through investment, the source of property income receipts, does not require similar activity on the part of individuals and is compatible with extensive participation in other activities. To be sure, property investment is sometimes embodied in the individual's training and skill, and the return for the services of individuals contains a substantial element of return for the services of property. Yet the difference between income payments in compensation for direct activity by individuals and for the services of their property holds for a wide range of comparisons.

One type of compensation for individuals' services may be designated labor income; another, entrepreneurial income. The former represents compensation for services rendered by individuals who have little voice in the decisions an enterprise makes and can easily be separated from it. The latter includes compensation for the making of all the responsible decisions in the management of the enterprise.

This tripartite division into labor, entrepreneurial, and property income payments seems at first well represented by 
institutional categories of income streams to individuals, i.e., by wages and salaries, entrepreneurial net income or withdrawals, and dividends, interest, and rents and royalties. But further consideration reveals a lack of correspondence.

Entrepreneurial net income, as measured, is what accrues to entrepreneurs after the payment of all production costs. Entrepreneurial withdrawals are the amounts retained by entrepreneurs for their own consumption and for investment outside their firms. These income payments or withdrawals, as they accrue to or are made by groups of entrepreneurs (farmers, miners, retail traders, small construction contractors, etc.) are, from the viewpoint of the functions they represent, a hybrid of all three types. A majority of entrepreneurs perform actual, physical productive functions that, under a different form of business organization, are performed by wage earners or salaried employees. All entrepreneurs exercise managerial discretion and make the decisions vital to the enterprise both internally and in its relations with other enterprises. An overwhelming proportion of entrepreneurs have a net property investment in their enterprise. The relative importance of these three forms of entrepreneurs' participation varies from industry to industry; but dividing entrepreneurial income or withdrawals into labor, entrepreneurial, and property income would be so arbitrary as to serve no useful purpose. What the preponderant element in it is for the country as a whole is hard to say; but since in the group receiving entrepreneurial income farmers, retail merchants, small construction contractors, and professional people predominate, the category is by and large that of service rather than of property income; and perhaps preponderantly that of labor income rather than of entrepreneurial income.

Rent raises a somewhat different question. Net rent paid to individuals is largely for urban real estate, that flowing from farm property and other extractive sources being relatively minor. Recipients of rent typically take a more active part in managing their property than holders of stocks or bonds, who 
merely draw dividends or interest. Hence the category is a combination of property and entrepreneurial income. If the element of entrepreneurial activity were substantial enough, a recipient of rent could be classified as an entrepreneur in real estate rather than as an individual recipient of property income originating in whatever industry pays the rent. If this were done, rent would not be classified as a separate type of payment but would become an income stream from one industrial branch in our classification. Alternatively, rent could be treated as purely property income and its origin traced to various industries, among which residential real estate is one. There may also be intermediate treatments. For example, rent from agriculture can be considered property income originating in agriculture, and all other rent, entrepreneurial income from real estate; or all rent can be classified as property income but assigned to real estate.

There is no decisive reason for our choice of the last-mentioned method. Had we the proper data, we could perhaps segregate the net rent that represents purely property income from that which is compensation largely for entrepreneurial activity. Since such data are lacking, it seemed best to treat rent as property income, comparable with dividends and interest. As property income, rent should have been apportioned among the industries in which it originated (similarly to dividends and interest); but for lack of continuous data on rent originating in the various industries (except in agriculture and one or two other branches) all rent had to be assigned to real estate.

There is little information on royalties with which we could segregate, estimate, or classify them definitely as property or entrepreneurial income. They are probably almost entirely a return on property, acquired either through direct monetary outlay or an outlay of labor, although some royalties imply more entrepreneurial activity than is manifested by recipients of dividends and interest. The item is so small that 
it can be disregarded and since it cannot be estimated separately on a continuous annual basis, we omit it.

In the total income of employees, how should we treat 'other income' and to what extent are elements of entrepreneurial and property income contained in wages and salaries, particularly the latter? 'Other income' is a miscellaneous category made up of pensions, compensation for injury, ${ }^{4}$ and relief payments. The second alone has a close connection with current services rendered in the production process. But all three are based upon a substantial connection with active participation in the production process in the past. If we disregard timing, it is reasonable to describe all three as payments to individuals for their services rather than for the services of their property. In this respect they are similar to wages and salaries. Consequently we designate them as 'other income of employees' and include them in our estimates under the more comprehensive total, employee compensation.

There is one substantial element of property income in both wages and salaries, and at least two minor ones in salaries. The important factors in higher rates of compensation to some wage earners and salaried employees are their education and training and the scarcity of the natural capacities needed for the service they render relative to demand. The part of wages and salaries derived from higher rates of compensation due to these factors may be considered property income payments, i.e., returns on the investment made in the past in education and training or on the value of a natural resource monopolized by its possessor. The share of wages, and more especially, of salaries, that could be interpreted as property income is often substantial, e.g., among professional employees.

Of the other elements of property income in salaries the first and more obvious is contained in the compensation paid

4 The one industry for which we show this item is steam railroads, Pullman, and express. Compensation paid to persons other than employees is included, since it could not be segregated. The amount in question is probably relatively small. 
for a sinecure obtained by a property investment, rather than for any productive activity or only in minor degree for services rendered. A job is awarded to someone who has made or is making a property investment to the benefit of the groups in control of the appointment. Theoretically, such payments are on a par with charity contributions by enterprises on the one hand, with dividends and interest on the other. Data do not admit of their segregation, but their total is probably not large.

The second additional element of property income in salaries is in the compensation of corporation executives. When the owners of a corporation are also officials, their salaries are identical with entrepreneurial withdrawals; and to the extent that entrepreneurial withdrawals include an element of property income, so do salary payments to the owners of these pseudo-corporate units. This item also cannot be segregated but is probably relatively minor. It is absolutely much larger in big corporations: the executive personnel, though theoretically subordinate to the stockholders, are actually very influential in making decisions and are, to all intents and purposes, the entrepreneurs. The main distinction lies not in their presumed subordination to the controlling bodies, but in the size of the enterprise. Any enterprise that has attained a certain size must rely for its entrepreneurial functions not on an individual and mortal owner, but on a more powerful and self-perpetuating group of executives.

In large enterprises the necessity of apportioning entrepreneurial functions among many people makes for gradations of power among employees, and the point at which a given employee ceases to be an entrepreneur and becomes a subordinate is often not apparent. The part of salaries that represents compensation for entrepreneurial activity, therefore, cannot be calculated precisely, but it can be approximated and we must not forget that salaries, which are often treated as representing labor income, include substantial elements of entrepreneurial income. 
Thus the distinction between payments for services and for property cannot be clearly drawn on the basis of the institutionally prevalent types of payment. There are elements of property income in salaries and in entrepreneurial net income or withdrawals; and an element of service income in rent. Yet by and large, wages, all except executive salaries, and most entrepreneurial net income or withdrawals, are preponderantly service income; dividends, interest, and rent are even more preponderantly property income. If compensation for purely entrepreneurial functions is to be distinguished from other service income, elements of it will be found in salaries, rent, and, to a minor extent, even in dividends; but there is no single, institutionally recognized type of payment in which it is quantitatively predominant.

\section{B WAGES AND SALARIES}

As already mentioned, salaries include a more substantial element of property and entrepreneurial income than wages. But this difference is too elusive and variable to serve as the basis for the segregation by enterprises of these two types of payment. The salary of a filing clerk or of a typist includes perhaps a smaller element of property and entrepreneurial income than the wages of many a skilled worker.

Of the various bases on which the two might be distinguished-proximity to and directness of participation in the production process; manual and non-manual character of the services rendered; training and education required; method of payment (piece or time); periodicity of payment (hour, day, week, month, year, etc.); size of compensation-none seems adequate by itself. Some employees participating in the auxiliary functions of the enterprise are classified as wage earners (e.g., construction workers in a factory, repair men, watchmen). Some salaried employees seem to perform primarily manual functions (e.g., multigraph machine operators, draftsmen). The education and training required of many skilled wage earners is not substantially less, and is sometimes more, 
than that required of recipients of salaries. Many wage earners are paid on a time basis; many salaried employees are virtually on a day and hour payment basis; others (e.g., salesmen) may be on a commission basis.

The answer seems to lie in a combination of these criteria, of which proximity to and directness of participation in the production process and the manual character of operations seem to have most weight. These two factors constitute the basis for other differences between wages and salaries. The manual character of operations explains the fewer prerequisites of education and training that differentiate most wageearning jobs from most salaried occupations. Directness of participation in the production process explains a piece rate basis of wages in many industries and the payment of wages for time units much shorter than those used for salaries in most industries. Finally, direct manual participation in the production process usually means that wage earners do not engage in administrative and entrepreneurial functions, renders wages largely prime rather than overhead costs, and, demanding as it does few prerequisites of education and training, is a factor making for the lower levels of most wages as compared with salaries.

The distinction between wages and salaries is not worth making in all industries. There is little meaning in it when the production process does not involve much manual labor. For example, banks, insurance companies, educational institutions, professional enterprises, governmental agencies, and even trade, draw no clear-cut line between wages and salaries. The term 'wages' in such industries is confined to the compensation of the few employees who perform manual labor (construction and repair men, charwomen, etc.), and applies to so small a part of total payments to employees that the distinction is not important. Even industries that employ a large amount of manual labor in extracting, transforming, and transporting commodities make the distinction only if, in addition 
to employees engaged directly in these processes, there is a substantial group performing administrative, research, supervisory, or entrepreneurial functions. Where, as in agriculture, such a group is absent or exceedingly small because the size of the entrepreneurial unit reduces such functions to a minimum and leads to their performance by the entrepreneurs themselves, the distinction between wages and salaries again is not worth while. For this reason, our estimates segregate wages from salaries for only such industries as mining, manufacturing, construction, and steam railroads.

The distinction between wages and salaries in some industries forces us to segregate these industries, one by one. In others the characteristics of the functions compensated by the combined wage and salary or salary payments vary considerably. The very factors that force the separation of wages and salaries in industries like mining and manufacturing make desirable an industrial allocation of total employee compensation among trade, personal service, government, etc.

It would be illuminating also to have wages classified on the basis of skill and training, occupation in primary or auxiliary functions, method of payment (piece or time), and amount of compensation. Similarly, it would be useful to have salaries divided into their property and entrepreneurial elements; among various types of administrative, supervisory, etc. activities; by basis and level of compensation; and by the degree to which they represent prime or overhead costs. Such classifications, with the possible exception of the segregation of compensation of corporation officers from other salaries, are barred by lack of data. This lack of data is not accidental: the allocations suggested demand a close analysis of employee compensation within each enterprise. Only when the need for such an analysis is forced upon an enterprise by its own development or by the concern of public agencies for the stability of employee compensation (as under social security legislation) are some of the allocations suggested made. 


\section{DIVIDENDS AND INTEREST}

The distinction between interest and dividends reflects the character of the obligations assumed by the paying enterprise. The obligations giving rise to interest are rigidly fixed with reference to the repayment of principal (as in savings banks), or to the continuous payment of interest (as in non-redeemable bonds), or to both (as in practically all bonds issued by business enterprises). The payment of dividends reflects no such obligations. Though many business units pursue a policy of maintaining stable dividends in order to remove speculative elements from the purchase or holding of their stocks, they are in a position to vary disbursements when conditions are markedly above or below ordinary levels, and usually do so. By contrast, even when there is no definite obligation to pay interest the existence of an obligation to repay the principal is conducive to a conservative investment policy and to a temporal stability of interest payments. Since dividends fluctuate and interest is relatively stable wè separate these two types of property.income.

With this basic difference between interest and dividends two others are associated. The first is the presence in dividends, but not in interest, of an appreciable element of entrepreneurial income. Short term changes in dividends distributed by enterprises reflect the skill with which they have met changing economic conditions and fluctuations in the markets. And if under entrepreneurial income we include, among other elements, compensation for their success or failure, dividends obviously contain a substantial share of entrepreneurial income. On the other hand, interest on bonds, which carry legal obligations, can reflect business conditions only when default occurs, a concomitant of that extreme failure of entrepreneurial activity that occurs chiefly during depressions.

A corollary aspect of the difference between interest and dividends is that they go largely to people in substantially different income groups. Dividends represent a return on the more spec- 
ulative investment, requiring a discernment and knowledge of opportunities that possessors of small savings usually do not have, and bestowing a right to participate in the affairs of the enterprises not desired by a small investor or accessible to one who holds only a few shares of stock. For these reasons the great bulk of stocks are held by large investors; and at least in this country, by far the major portion of all dividends disbursed to individuals is received by people enjoying incomes well above the average. Interest paying investments, on the other hand, appeal to small investors; and a large share of interest paid to individuals is received by people with moderate incomes.

While this generalization is on the whole true, two qualifications must be kept in mind. The first and more important is that the groups of people receiving interest and those receiving dividends overlap considerably, not only because the same individual may receive both, but also because some individuals with low incomes receive dividends and some with high incomes receive interest. The second is that interest and, to a much smaller extent, dividends, frequently flow from enterprises to individuals via some agency such as a savings bank or insurance company rather than directly. When such agencies intervene and we cannot separate the interest flow to them from their payments to individuals, interest does not necessarily measure current interest receipts by individuals, and cannot be compared with dividends. The intervening agencies may retain a part of the payments originating in the industries proper, or add to them from accumulated reserves; and there may be some disparities between actual receipts by individuals and the estimated net interest originating in the economic system.

\section{DISTRIBUTION OF PAYMENTS BY SIZE}

The usefulness of the distribution of family income receipts by size classes cannot be realized fully unless it is supplemented by a distribution of the size and other characteristics of the family, of other economic resources at the disposal of families, and of the sacrifices incurred in obtaining income. 
Yet its value in the treatment of various problems of economic analysis and in the interpretation of changes and differences in national income totals is great, even when it alone is available. Its contribution to any interpretation of the welfare equivalents of the income flowing to individuals from economic enterprises is patent. Its importance in the social conflict economic activity engenders between the 'haves' and 'have-nots' is equally clear.

To construct this distribution we need to know how much income each family received. It is not sufficient to know the distribution by size of each type of payment separately, since many individuals and families receive more than one type. The ideal, of course, would be to have the distribution by size combined with that by type, cross-classified by industrial origin. Such a combination of characteristics-size, type, and industrial origin -would shed light not only on differentiae with respect to current income receipts but, by segregating property income, would suggest the existence or absence of additional resources, and would also indicate differences in the standard of living of recipients and the sacrifices implied in the process of earning. However, the unit in this distribution would still be the family, not the industry or enterprise in which payments originate.

It is this circumstance that makes the construction of a distribution of payments by size so difficult. As indicated in the next chapter, most of the continuous, comprehensive data for this country are for activities of enterprises and industries; and records of income receipts of individuals or families have, until very recent years, been confined to the small group that file income tax returns. Direct and comprehensive information on the distribution of income receipts by size is not available even for a single year, let alone continuously. We must therefore consider substitutes and approximations.

The first and most obvious substitute is the distribution by type of payment. As noted, one criterion of distinction between wages and salaries is the size of average payment; and one difference between dividends and interest is that a preponderant 
part of the former is received by people with incomes much larger than those of people who draw the preponderant part of the latter. Entrepreneurial income or withdrawals also are the source of low average incomes, being in the main receipts of small proprietors. Indeed, a great deal of the public interest in the distribution of payments by type lies in its identification with a distribution by size and among social groups. Shifts in the share of wages are interpreted as changes in the shares of the low income groups; and similar interpretations are applied to changes in the distribution between service and property income, or between entrepreneurial withdrawals and property income.

We have already indicated how crudely an allocation by type approximates a distribution by size. We point out here merely that departures from a true distribution by size are greater when it is among family units than when it is among individuals. Among the former there is more opportunity for income from several sources and greater possibility that substantial incomes from a combination of wages and/or salaries will raise a family to a higher income category than it would be in if classified by any one source. Moreover, although incomes from wages and salaries, or interest and dividends, or labor and property differ greatly, the hybrid category of entrepreneurial income or withdrawals is not so clearly separable from the others with respect to the income size class to which it gives rise. In some industries entrepreneurial income payments or withdrawals are akin to wages; in others, to salaries; in still others they tend to yield high bracket incomes.

This suggests one more reason for cross-classifying types of payment by industrial origin. Differences in average levels of wages and salaries prevail from industry to industry; and the like, as just indicated, is still more true of entrepreneurial income or withdrawals. Even dividends and interest may differ in this respect among industries, because of differences in the speculative character of the industries and in the net property return they yield. Thus the multiplication of cells serves to 
suggest more accurately differences in size categories within total income payments to individuals and families. True, an increase in subdivisions increases the probability that one individual or family will draw income from more than one cell. But the possibly increased overlapping is surely more than offset by the greater precision with which differences among payments by size classes would be revealed.

\section{Summary}

Four types of classification may be used in studying the composition of the national income total: analytical, evaluative, empirical, and institutional. Analytical classifications are based upon the analysis of economic reality provided by economic theory and its various applications, analysis that attempts to establish the various factors making for stability and change and the interrelations among them in determining economic phenomena. Distributions like that among labor, entrepreneurial, and property income types, or between monopolistic and competitive industries are good examples.

The evaluative type distinguishes categories within which, for substantial or imaginary reasons, the contents of national income are to be evaluated differently. Extreme examples arise from violent prejudices or partisanship. If one happens to believe that blondes form a distinct and exalted group, then income payments should be apportioned between fair-haired and other recipients. But usually the grounds of distinction are somewhat more cogent, resting upon a recognition that types of activity or groups of individuals should be segregated for substantial reasons of similarities and differences in pattern of life and consciousness of kind. A good illustration is the distribution of income payments among social groups (farmers, urban manual workers, white collar employees, small business men, etc.).

The empirical type of classification is based upon categories that have behaved in significantly different ways in the past and hence should be segregated for the present and future as 
a help in diagnosing changes in the national total. It is difficult to find an illustration of a purely empirical classification, but it could be exemplified by the hypothetical case of an investigator who classifies data on net values originating in each enterprise of the country into groups exclusively by the way they changed in the past.

The institutional classifications are based upon the categories in which the statistical data come. They follow the divisions determined by the institutional framework of economic activity as reflected in current statistics, which, while often suffering from sins of omission, rarely err by departing from institutional categories. Any book on national income affords numerous illustrations of such institutional classifications.

While these four types of allocation differ sufficiently to warrant their separation, they have a great deal in common. Economic analysis is not an exercise of the imagination detached from reality, but must consider the institutional framework of economic activity and deal with the institutions that are reflected in the statistical data. Nor are the factors analyzed without influence upon the groups or types singled out in evaluative classifications: they are at least one among several sets of factors that differentiate one social group or one type of activity from another. Whatever other factors are involved in such evaluative classifications, a goodly proportion must be reflected in the data and hence in the institutional classifications. The purely empirical allocations also have considerable kinship with the analytical and institutional: they are usually based upon institutional categories characteristic of the statistical data in the past, and if consistently observed, give clues to combinations of factors susceptible to economic analysis.

The investigator must perforce adhere to institutional classifications. Purely empirical allocations are few and unreliable, since adequately accurate estimates of national income do not cover a period or a number of countries sufficient to yield empirically established distinctions. And in order to assign quantitative counterparts to analytical or evaluative categories, 
he should either be able to go behind the published summary statistics and reclassify the original returns from enterprises or individuals, or be in a position, by expenditure of time and ingenuity, so to readjust the institutional divisions in the published data as to get good approximations to analytical and evaluative categories. The former opportunity is usually lacking and the latter severely limited.

For this reason our estimates present chiefly the institutional classifications of industrial origin and type of payment, with a single and broad analytical allocation among withholdings, disbursements, and consumers' outlay. For the same reason we discuss in this chapter primarily these three classifications. The classification among withholdings, disbursements, and outlay, being largely analytical and having been made by means of extensive readjustments and recalculations, is discussed in order to show clearly the lines drawn between the various categories and the allocation of doubtful items. In the classifications by industrial origin and by type of payment there was no need to clarify the distinctions made familiar by everyday discourse. The main purpose was to indicate the extent to which these institutional classifications conform to or differ from the analytical and evaluative ones they approximate but with which they are often treated as identical. Thus, a distribution among industries is not synonymous with that among types of productive activity or among social groups characterized by their industrial attachment. Similarly, the distribution among wages and salaries, entrepreneurial net income or withdrawals, and dividends plus interest and rent is not identical with the analytical distinction between labor, entrepreneurial, and property incomes. Even though, without actually carrying through the analytical and evaluative classifications, we cannot indicate how far the institutional classifications depart from them, we must not forget that they do. Finally, we suggested the possible combinations of classifications and indicated their use in translating the institutional allocations into the analytical and evaluative categories they approximate. 